\title{
Institutional Investors' Monitoring Roles in State Controlled Firms and Income Smoothing Analysis for Stable Growth and Sustainability: Focusing on China Stock Market
}

\author{
Meng-Jun $\mathrm{Xu}^{1}$ and Dong-Il Kim²** \\ 1 Dept. Business Administration, Ph.D. Course, Pusan National University, \\ Geumjeong-gu 46241, Busan, South Korea; xmj1992@pusan.ac.kr \\ 2* Dept. of Business Administration, Professor, Pusan National University, \\ Geumjeong-gu 46241, Busan, South Korea; kdi50@pusan.ac.kr

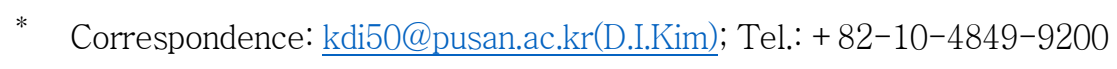

\begin{abstract}
The purpose of this study is to examine the relationship between the institutional investors which can affect financial performance for corporate sustainability on the income smoothing. Therefore, this study focus on the connection between the nature of stock rights and income smoothing in China. For this study, hypotheses were established on the relationship each state-controlled companies, income smoothing, and information equilibrium of individual investors, and empirical analysis was conducted through related variables. The analysis results are summarized in three categories as follows. First, this research finds that state-controlled firms (CONTs) prefer income smoothing activities compared to nonstate-controlled firms for the long-term sustainable development of firms using data from 2011 to 2019. Second, this study found out that Institutional investors support the behavior of CONTs to smooth their earnings because this behavior is seen as an attempt by CONTs to convey valuable private information to other investors. Third, we was able to discover that institutional investors' monitoring effect is predominantly driven by pressure-resistant institutional investors. This research complements the lack of empirical research on income smoothing and enable to give a guideline that the type of stock rights is a critical key determinant of participation in income smoothing activities for stable growth and sustainability in the future.
\end{abstract}

Keywords: Nature of stock rights; State-controlled firm; Income smoothing; Institutional investor; Pressure-resistant institutional investor; Pressure-sensitive institutional investor

\section{Introduction}

It takes a long time series to study the income smoothing phenomenon. China's capital market was established later than that of Western countries. Most academic studies on income smoothing directly draw on the conclusions from foreign countries, and there is a lack of indepth research on the income smoothing phenomenon in China's emerging capital market. However, with the gradual improvement of China's capital market development, 
although there are few studies on income smoothing at present, it does not mean that firms do not have an income smoothing phenomenon. The research on income smoothing can help us correctly understand its role in the quality of accounting earnings information, and understand the operating mechanism of China's capital market and the behavior characteristics of investors, to improve the efficiency of resource allocation in China's capital market and promote the sustainable development of the capital market. Therefore, China should focus on practical problems and the significance of income smoothing. In a study on the price of earnings management among countries, Bhattacharya, Daouk, and Welker [1]found that China's income smoothness is substantially greater than in other emerging economies, ranking second only to South Korea among 19 capital markets in emerging countries.

Starting from the information function of income smoothing, scholars believe that income smoothing can be used as a communication tool for managers to reflect private information about future earnings, and they believe that income smoothing can directly or indirectly enhance enterprise value. Furthermore, investors can also better understand the performance of enterprises through income smoothing [2]. Starting from the opportunistic hypothesis of income smoothing, scholars believed that income smoothing would disturb the effectiveness of information transfer in capital markets, reduce the quality of accounting information, enhance enterprise value, and lead to poor judgment of investors[1, 3].

Graham, Harvey, and Rajgopal [4] surveyed and interviewed 401 corporate finance executives to understand the drivers of earnings reporting and disclosure decisions. Their research found that $96.9 \%$ of interviewees expressed a preference for income smoothing, and $78 \%$ of interviewees were even willing to give up the actual economic value of the enterprise for the sake of income smoothing. Leuz, Nanda, and Wysocki [5] also confirmed that income smoothing is a kind of accounting phenomenon that exists all over the world. So whether most companies participate in income smoothing, and what business consequences are generated by income smoothing is affected by many factors. Starting from the actual situation of Chinese enterprises, this paper selects two aspects for consideration and analysis: the nature of stock rights and institutional investors.

In recent years, the main body of institutional investors has diversified, the scale of institutional investors has expanded, and their role in China's capital market has become increasingly important. Velury and Jenkins [6] believed that compared with other investors, institutional investors are more adept at analyzing financial statements. Lu Jiayou and Li Yanmei [7] showed that institutional investors play a positive role in improving corporate performance and internal controls. Hu Yize, Shan Jun, and Zhan Peixun [8] pointed out that institutional investors choose to invest in companies with better corporate responsibility and monitor the sustainability of their portfolio companies. Li Zhengguang and Guo Haoran et al. [9] found that with the support of the Chinese government, institutional investors have gradually become one of the important shareholders of listed companies in China. Securities investment funds, qualified foreign institutional investors (QFII), insurance companies, social security funds, financial companies, and banks are all examples of Chinese institutional investors. Various types of institutional bodies, on the other hand, serve different roles. Therefore, the heterogeneity of institutional investors should also be taken into account when examining institutional investors. Sahut and Gharbi [10] divided institutional investors into three types: pressure-sensitive and pressure-resistant, dispersed and concentrated, and active 
and passive. According to the actual situation in China, according to whether there is an actual or potential business relationship between institutional investors and the invested companies, Brickley [11], considering the independence and monitoring role of institutional investors, divides institutional investors into pressure-sensitive institutional investors(PSII) and pressure-resistant institutional investors(PRII). Securities investment funds, QFII, and social security funds are examples of PRII, whereas insurance companies, trust companies, securities companies, and financial companies are examples of PSII.

In China, state-controlled companies account for a high proportion of all listed companies, and there are great differences between CONTs and non-CONTs in the corporate governance structure. According to the fourth national economic census report released by the National Bureau of Statistics on November 27, 2019, China had 242,000 CONTs at the end of 2018, 24,000 more than at the end of 2013, an increase of $10.9 \%$. Although the number of CONTs only accounts for $1.3 \%$ of all firms, they employ $15.7 \%$ of the workforce in China. Hence, they remain critical in national economic development. Li Yuxuan, Miao Xin et al. [12] pointed out that state-controlled firms are the bellwether of implementing government policies in China. When investing in CSR activities, they are under more pressure from governments and assume greater social responsibilities, leading to higher costs and lower financial efficiency. As a country with a unique political system, China also needs to take into account the differences caused by differences in equity properties of listed companies when researching corporate performance and sustainability issues.

Through the above introduction, we carry on the following discussion on this paper. Firstly, this study explores whether the nature of stock rights is related to the smooth returns of enterprises. According to the political cost hypothesis, reputation theory, and information transmission hypothesis, whether state-controlled firms prefer smooth incomes. Chwee Ming Tee [13] conducted a study on the capital market of Malaysia and found that politically connected firms have a significant positive relationship with income smoothing, and politically connected firms with long-term political relations are more likely to smooth incomes. The second research question examines whether institutional investors' shareholding ratio can adjust the relationship between equity nature and income smoothing. There is evidence that institutional investors are more inclined to companies with stable income streams [14, 15]. When managers' motivation for income smoothing is to convey useful private information to investors, investors can learn more about the real performance of companies, and institutional investors will encourage companies to smooth income $[2,16]$; When managers' motivation for income smoothing is for self-interest, the interests of investors will be harmed, and institutional investors will play an effective supervisory role to restrain the income smoothing behavior of companies [1]. Therefore, if the behavior of company smoothing income is to convey useful information to investors, institutional investors prefer income smoothing, otherwise, it will weaken the company income smoothing motivation. This study examines the main motivation of company income smoothing through the moderating effect of institutional investors on income smoothing in CONTs. Finally, considering the heterogeneity of the main body of institutional investors, this paper examines whether different types of institutional investors affect the income smoothing in CONTs.

To verify the above research issues, this paper uses 5,049 annual observed values of $561 \mathrm{~A}-$ share listed companies in China's Shanghai and Shenzhen stock exchanges from 2011 to 2019 
and draws the following conclusions. Firstly, we find that there is a significant positive correlation between CONTs and income smoothing, which shows that income smoothing is more common in CONTs than in non-CONTs. It can be explained that CONTs, considering their political relevance, are more likely to reduce the excessive attention of the outside world through stable earnings for the sake of long-term development goals. Secondly, this correlation is more prominent in CONTs where institutional investors hold a high proportion of shares. That is, the supervisory duties of institutional investors have a positive effect on the smoothing income of CONTs, which means that the motivation of CONTs smooth income is primarily to convey useful private information to investors and other stakeholders, and institutional investors encourage this behavior. Finally, when considering the independence of institutional investors, we found that institutional investors' regulatory effect is mostly realized through PRII and that PRII and PSII are sensitive to income smoothing in distinct ways. Considering China's unique political system, this research not only complements the shortcomings of China's capital market in the study of income smoothing but also expands the related research scope of institutional investors.

\section{Literature Review and Hypotheses Development}

\subsection{Nature of stock rights and income smoothing}

In China, because the local government (competent department) is deeply involved in managing CONTs, CONTs have the function of showing their political achievements. Local governments also provide subsidies, tax breaks, and other support to stimulate the growth of listed companies. In this case, to obtain financial support, CONTs will reduce profit fluctuations and create a stable profit flow to meet the requirements of the sustainable development of firms. However, under political protection, CONTs suffer from opaque financial reports, resulting in a serious loss of management efficiency, and are insensitive to changes in the macroeconomic and market environments. Yang Jisheng and Yang Jianhui [17] pointed out that the sensitivity of private controlled firms to environmental factors is 5.5 times that of CONTs. In addition, many managers of CONTs are appointed by competent authorities and have a certain administrative level. Therefore, the business performance of the company plays a very important role in the political future of these managers. Especially in the information age, when the media promotes social topics and guides public opinion, CONTs may adopt the phenomenon of stable earnings to improve their corporate reputation. Watts and Zimmerman's[18] political cost hypothesis assumes that companies with high political relevance will be subject to strict supervision by regulators and attention from the public and media. Wang Peng et al. [19] found that due to fear of administrative intervention, CONTs managers are more motivated to cover up their earnings management behavior through the media to maintain their "positive" image. Wu Gaobo and He Fangfang [20] believed that compared to the management of non-CONTs, the management of CONTs has a stronger desire to reduce earnings management. Chwee Ming Tee [13] discovered that politically associated firms prefer smooth income. According to the reputation theory, managers of politically associated firms with a long history are more motivated to smooth income to maintain a positive reputation in capital markets. In addition, the study of Zhou Hui [21] pointed out that the salary and remuneration of middle and senior managers of CONTs are linked to the performance of firms. A greater degree of earnings management results in a closer relationship 
between managers' remuneration and business performance. Therefore, to reduce the unnecessary attention of CONTs from the public, managers need to cover up poor business performance through smoothing earnings and create a positive social image. Second, managers of CONTs may gain further political prospects or higher salaries by smoothing out corporate incomes. But this kind of opportunistic behavior covers up fluctuations in corporate performance, which will hurt other shareholders and affect enterprise value.

However, from the signal theory, income smoothing can also be seen as a way for managers of CONTs to convey private information to users. Many theoretical studies support income smoothing as a means of communicating private information about future earnings. They believe that income smoothing sends signals of performance and play an effective role in information communication. Subramanyam [22] found that managers used income smoothing to reveal private information about future earnings. Tucker and Zarowin [2] pointed out that if managers use their discretion to convey their assessment of future earnings, return smoothing may help investors obtain information concerning earnings. Some scholars also believe that compared with enterprises that do not engage in income smoothing, income smoothing firms have better performance. Michelson et al. [23] proposed that companies with smooth incomes tend to have higher excess returns compared with companies without smooth income characteristics. Zheng Xincheng [24] found through empirical analysis, income smoothing could improve the sustainability and predictability of earnings data, thus improving the decision-making relevance of earnings. In China, there is a natural internal connection between CONTs interfered with by the government. Such a "relationship bond" enables holding firms to receive greater financing opportunities and greater advantages in the process of resource allocation by governments $[25,26]$. But managers can use a steady income as a precautionary measure if they are unable to sustain performance due to special reasons (such as a financial crisis or the absence of relevant government departments). CONTs then smooth out incomes to convey more valuable information to investors concerning business sustainability. So regardless of the purpose of smoothing incomes of CONTs, our first hypothesis is as follows:

H1: State-controlled firms are more likely to smooth income.

\subsection{Nature of stock rights, income smoothing, and institutional investor's monitoring}

Compared with individual investors, institutional investors have the advantage of obtaining and effectively processing timely information to make efficient investment decisions. Moreover, when corporate performance declines or fluctuates, institutional investors can make use of their advantage of capital scale to alleviate the operation fluctuations of the firm. If institutional investors can better monitor opportunistic earnings reports when the management's investment decision violates the corporate value, the quality of earnings will improve with the increase of institutional investor holdings, which reflects the monitoring role of institutional investors. Chakravaty [27] found that the information advantage of institutional investors is significantly correlated with their shareholding ratio. In other words, the higher institutional investors' shareholding ratio in listed companies, the more non-public information they have access to, and the more supervision they exert. Velury and Jenkins [6] found through empirical analysis that higher institutional investors' shareholding ratios led to higher-quality accounting 
information, and institutional investors can play a monitoring role in the management. Hideaki Sakawa and Naoki Watanabel [28] showed that institutional investors' monitoring role plays an effective role in Japanese firms, and institutional investors' shareholding is conducive to improving sustainable corporate performance. Song $\mathrm{Yu}$ and Fan Minhong [29] found that the institutional investors' shareholding ratio is positively correlated with the degree to which the stock price reflected future earnings information, and institutional investor holdings accelerated the degree to which the future earnings information was reflected in the stock price. Miao Luo et al. [30] investigated the institutional investor behavior in the Japanese stock market and discovered its presence increased the information content of stock prices, which could weaken irrational investment behaviors and thus stabilize stock prices.

If institutional investors are regarded as ineffective supervisors, it will have a bad impact on their image and thus lose the support of investors. Evidence shows that institutional investors are more inclined to enterprises with stable income streams when the motivation of companies to smooth earnings is to deliver useful information to investors [14, 15], the regulatory role of institutional investors is considered effective; when the manager's motivation for smoothing earnings is for self-interest, income smoothing will disrupt the effectiveness of information transmission in the capital market and harm the interests of investors, and institutional investors will restrain the income smoothing behavior of companies [1].

When considering the nature of institutional investors in company equity, Bo XianHui and $\mathrm{Wu}$ Liansheng's [31] study found that institutional investor holdings in private listed companies and CONTs' earnings management effect differs. That is, the type of controlling shareholder will affect the relationship between institutional shareholding and corporate earnings management. Li Zengfu and Lin Shengtian et al. [32] found that institutional investors are beneficial to corporate governance. Both CONTs and non-CONTs can effectively inhibit real earnings management, but institutional investors of CONTs have significantly less inhibitory effects on real earnings management than non-CONTs. Shleifer and Vishny [33] believed that institutional investors have strong information processing ability and access to inside information, and they play the role of information transmission in capital markets. Menkhoff and Schmeling [34] found that more information held by institutional investors resulted in lower trading volume in stock markets and the more inclined they are to conduct secret transactions, which is conducive to stock market stability. Chwee Ming Tee [13] pointed out that institutional investors who convey valuable private information can strengthen the relationship between politically connected companies and income smoothing. Therefore, if institutional investors can deliver useful information through personal advantages, the relationship between CONTs and income smoothing will be strengthened. Our second hypothesis is as follows:

H2: Institutional investors improve the relationship between CONTs and income smoothing if income smoothing is used to convey private information.

\subsection{Nature of stock rights, income smoothing, and institutional investor's heterogeneity}

Existing studies have found that institutional investors are not homogenous and have significant differences in their supervision and corporate governance effects. Therefore, this paper classifies institutional investors reasonably in consideration of the heterogeneity of 
institutional investors to ensure the reliability of the research conclusions. Based on previous studies, INST is divided into PRII and PSII [11, 35-38]. Institutional investors who only have investment relationships with listed firms have sufficient motivation to supervise management, which is called PRII. However, institutional investors with business dependence relationships with listed companies usually only hold neutral or even fully support the decision-making of the management, which is called PSII. Based on Hypothesis 2, we investigate whether there are significant differences between PRII and PSII in promoting the relationship between CONTs and income smoothing.

Mehrani S and MoradiM et al. [39] divided institutional investors into active institutional investors and passive institutional investors. By measuring all aspects of earnings quality with a multi-dimensional approach, they found that institutional investors played an important role in the company, and institutional ownership had a positive effect on earnings management. Ilhang Shin and Sorah Park [40] divided institutional investors into domestic institutional investors and foreign institutional investors according to geographical origin to examine the monitoring incentives of institutional investors. Chwee Ming Tee [13] divided institutional investors according to their geographical position as domicile institutional investors and foreign institutional investors. Due to domicile institutional investor's geographical location advantages and ease of regulation of firms, domicile institutional investors strengthen the relationship between politically associated firms and income smoothing. Ding Fangfei et al. [36] divided INST into PRII and PSII and concluded that PRII, such as securities investment funds, social security funds, and QFIIs, can help improve the transmission of future earnings information to stock prices. Qin Zhen [41] pointed out that the shareholding of PRII can promote the earnings sustainability of listed companies, while the shareholding of PSII cannot promote the earnings sustainability of listed companies. In other words, the higher the shareholding ratio of PRII, the better the earnings sustainability of a company. Because institutional investors subject differs across countries, many countries will be mutual fund and QFII classified as PRII, but China does not have the term mutual funds. Considering the independence of institutional investors, this article considered securities investment funds, social security funds, and QFII as PRII, while insurance companies, trust companies, securities companies, and financial companies are classified as PSII. If the PRII with strong independence has greater supervision over CONTs, will the motivation of smoothing earnings be stronger? Therefore, the final hypothesis is proposed:

H3: Pressure-resistant institutional investors (PRII) improve the positive correlation between CONTs and income smoothing if income smoothing is used to convey private information.

\section{Research method}

\subsection{Data and Sample Selection}

This paper selects all A-share listed companies in China's Shanghai and Shenzhen stock markets from 2011 to 2019 as our research sample. We used the following steps to screen the sample:

1)Excluded listed companies in the financial industry;

2)Excluded listed companies that were ST or * ST during the study period;

3)Excluded listed companies with incomplete information disclosure. 
In the end, 5049 annual observation values of 561 listed companies were obtained. Research data was obtained from the CSMAR database (equivalent to Compustat database in the United States), and SPSS26 was used for data analysis.

\subsection{Income Smoothing (IS)}

Income smoothing is a form of earnings management that refers to the use of accounting adjustment methods, such as accruals, to smooth earnings within the scope permitted by accounting policies. Its purpose is to show a sustainable and stable profit trend in financial statements. Earnings smoothing was first proposed by Hepworth [42]. Companies deliberately smooth corporate earnings and the formation of stable earnings will enhance the confidence of shareholders and creditors in the company. Michelson et al. [23] proposed that companies with smooth incomes tend to have higher excess returns compared with companies without smooth income characteristics. Huang Shengzhong, Chan Lyu, and Lin Xiaojun [43] pointed out that the role of income smoothing is informational; that is, the informative effect of income smoothing can improve the firm's future earnings informativeness. Income smoothing plays a dual role in determining earnings quality, which is the garbling or effective communication of private information [2].

In this paper, the method of Tucker and Zarowin [2] was used to measure the existence and smoothness of income smoothing; that is, to calculate the correlation coefficient between the change in discretionary accruals and the change in profit before manipulation in the current year and the past four years. The method used in this study is as follows:

1) The discretionary accruals, $\mathrm{DA}_{\mathrm{t}}$, and the change in discretionary accruals, $\Delta \mathrm{DA}$, were calculated using the modified Jones model

2) We calculated profit before manipulation $\mathrm{PDI}_{t}=\mathrm{NI}_{t} / \mathrm{A}_{\mathrm{t}-1}-\mathrm{DA}_{t}$ and the change in profit before manipulation $\triangle \mathrm{PDI}$

3) We calculate the correlation coefficient $\mathrm{Q}(\triangle \mathrm{DA}, \triangle \mathrm{PDI})$ between the change in discretionary accruals and the change in profits before manipulation over 5 years $(\mathrm{t}-4 \sim \mathrm{t})$. If the correlation was negative, it indicates that the sample company has carried out income smoothing. The closer the coefficient is to -1 , the greater the income smoothing degree is present.

4) According to the method of Tucker and Zarowin [2], the correlation coefficient is given a negative (-) sign to measure income smoothing so that the direction of the correlation coefficient is consistent with the intuitive direction of income smoothing; that is, IS= - Corr $(\triangle \mathrm{DA}, \triangle \mathrm{PDI})$.

\subsection{State-controlled firm (CONT)}

The nature of the management control of companies can be divided into CONTs and nonCONTs. CONTs are firms in which the state capital equity accounts for a higher proportion and is controlled by the state. Specifically, it refers to listed companies in which the government or state-controlled firms own more than $50 \%$ of the share capital, and these control rights or shares are enough to have a significant impact on the decisions at shareholder meetings. In this paper, nature stock right is set as a dummy variable. If the actual controller of the listed company is state-controlled, it is represented as 1 ; otherwise, it is 0 . 


\subsection{Institutional investors shareholding ratio (INST)}

Institutional investors refer to professional organizations or enterprises that use their funds to obtain investment income as their main business purpose. Institutional investors are not homogeneous, and they can be classified into different categories, as shown in Table 1. Referring to the practice of Brickley et al. [11], Yi Zhihong et al. [44], and Yang Haiyan et al. [45], this paper classified securities investment fund, social security fund, and QFII as pressureresistant institutional investors and denotes the sum of their shareholding ratio as PRII. Insurance companies, trust companies, securities companies, and financial companies are classified as pressure-sensitive institutional investors, and the sum of their shareholding ratios

\begin{tabular}{|c|c|c|}
\hline Classification method & Types & Related literature \\
\hline Investment horizon & $\begin{array}{c}\text { Transient institutional investors } \\
\text { Quasi-indexing institutional investors } \\
\text { Dedicated institutional investors }\end{array}$ & $\begin{array}{l}\text { Bushee [46] } \\
\text { Koh [47] } \\
\text { Dong and Ozkan [48] }\end{array}$ \\
\hline $\begin{array}{l}\text { Independent business } \\
\text { relationship }\end{array}$ & $\begin{array}{l}\text { Pressure-sensitive institutional investors } \\
\text { Pressure-resistant institutional investors }\end{array}$ & $\begin{array}{l}\text { Brickley et al. [11] } \\
\text { Cornett et al. [49] } \\
\text { Ding Fangfei et al. [36] } \\
\text { Qin Zhen [41] }\end{array}$ \\
\hline Geographic location & $\begin{array}{l}\text { Domestic institutional investors } \\
\text { Foreign institutional investors }\end{array}$ & $\begin{array}{l}\text { Ferreira et al. [50] } \\
\text { Aggarwal et al. [51] } \\
\text { Kim et al. [52] } \\
\text { Chwee Ming Tee [13] }\end{array}$ \\
\hline Monitoring cost & $\begin{array}{l}\text { Active institutional investors } \\
\text { Passive institutional investors }\end{array}$ & $\begin{array}{l}\text { Almazan et al. [53] } \\
\text { Chen et al. [54] } \\
\text { M Wang [55] }\end{array}$ \\
\hline
\end{tabular}

is referred to as PSII.

Table1. Heterogeneity of institutional investors

\subsection{Control variables}

(1) Firm Size (SIZE)

Firm size is calculated by the natural logarithm of the total assets of the firm. Large firms are often seen as politically more visible, and it's easy to catch public attention if there are big swings in income. Watts and Zimmerman [18] believed that larger firms are more likely to be noticed by the general public and relevant departments and will usually reduce the "cost of political attention" by smoothing income. Li Zengfu and Zhou Ting [56] found that to reduce their political costs, large-scale CONTs have a strong incentive to manipulate earnings. As a result, managers at big firms are more likely to use accounting discretion to reduce political concerns by reporting smooth earnings trends. Wagner and Wootton [23] found that smoother firms are larger than non-smoothing firms.

(2) Asset-liability ratio (LEV)

The ratio of a firm's total liabilities to its total assets at the end of the year, also known as 
financial leverage, is used to measure how close a company is to defaulting on its debts. When companies are closer to defaulting on their debt obligations, managers were more likely to exercise their accounting discretion. Firms with higher leverage ratios are more likely to engage in income smoothing to reduce borrowing costs. The debt contract hypothesis proposed by Watts and Zimmerman [18] points out that, under equal conditions, the higher the debt level of a firm, managers will have an incentive to choose accounting methods or policies that can adjust future earnings to the schedule.

(3) Return on Assets (ROA)

The return on total assets of a listed company represents the company's operating performance. Watts and Zimmerman [18] believed that when a company is in a particularly good financial standing, earnings management will be carried out to reduce the "political cost." When the company loses money, to turn a loss into a profit, the company will also carry out upward earnings management. Lei Guangyong, Liu Huilong [57], and Chen Donghua et al. [58] all found that ROA was positively correlated with earnings management.

(4) Book-to-market ratio (BM)

The ratio between book value and market value of a company is the book-to-market ratio. Lakonishok et al. [59] believed that the book-to-market ratio is an effective index to predict future stock performance, and companies with a high book-to-market ratio will have better performance in the future. Abdalla [60] found that the book-to-market ratio could reflect market growth opportunities and effectively predict macroeconomic growth trends.

\subsection{Establish research models}

In this paper, industry and year processing are set as dummy variables to control industrylevel differences and year changes, respectively, and the upper and lower $1 \%$ of all continuous variables are Winsorized to reduce the impact of extreme outliers. To test the above hypotheses and verify the relationship between variables, the following model is established.

Hypothesis 1 is tested using the following model:

$\mathrm{IS}_{\mathrm{I}, \mathrm{t}}=\alpha_{0}+\alpha_{1} \mathrm{CONT}_{\mathrm{i}, \mathrm{t}}+\alpha_{2} \mathrm{SIZE}_{\mathrm{I}, \mathrm{t}}+\alpha_{3} \mathrm{LEV}_{\mathrm{I}, \mathrm{t}}+\alpha_{4} \mathrm{ROA}_{\mathrm{I}, \mathrm{t}}+\alpha_{5} \mathrm{BM}_{\mathrm{I}, \mathrm{t}}+$

Year and Industry Fixed Effects $+\varepsilon_{\mathrm{i}, \mathrm{t}}$

Where:

the subscripts i and $t$ represent firm and year, respectively,

IS: income smoothing, which we compute using the negative correlation between the change in discretionary-accruals proxy $(\triangle \mathrm{DA})$ and pre-discretionary income( $\triangle \mathrm{PDI})[2]$,

CONT: a dummy variable set to 1 if the firm is a state-controlled listed firm, and 0 otherwise, SIZE: natural log of total assets,

LEV: financial leverage, the ratio of the company's total liabilities to total assets at the end of the year,

ROA: return on total assets, calculated as income before extraordinary items to total assets,

BM: book-to-market value ratio, the ratio of a company's book value to market value.

Hypothesis 2 is tested using the following model:

$$
\begin{aligned}
& I_{i, t}=\beta_{0}+\beta_{1} \operatorname{CONT}_{i, t}+\beta_{2} \operatorname{INST}_{i, t}+\beta_{3} \operatorname{CONT}_{i, t} * \operatorname{INST}_{i, t}+\beta_{4} \operatorname{SIZE}_{i, t}+\beta_{5} \operatorname{LEV}_{i, t}+\beta_{6} \mathrm{ROA}_{i, t}+ \\
& \beta_{7} \mathrm{BM}_{\mathrm{i}, \mathrm{t}}+\text { Year and Industry Fixed Effects }+\varepsilon_{\mathrm{i}, \mathrm{t}}
\end{aligned}
$$

Where: 
INST: institutional investors shareholding ratio, calculated by the percentage of shares held by institutional investors compared to the total shares outstanding,

Hypothesis 3 is tested using the following model:

$$
\begin{aligned}
& \text { IS }_{i, t}=\gamma_{0}+\gamma_{1} \text { CONT }_{i, t}+\gamma_{2} \text { PRII }_{i, t}+\gamma_{3} \text { CONT }_{i, t} * \text { PRII }_{i, t}+\gamma_{4} \text { PSII }_{i, t}+\gamma_{5} \text { CONT }_{i, t} * \text { PSII }_{i, t}+ \\
& \gamma_{6} \text { SIZE }_{i, t}+\gamma_{7} \text { LEV }_{i, t}+\gamma_{8} \text { ROA }_{i, t}+\gamma_{9} \text { BM }_{i, t}+\text { Year and Industry Fixed Effects }+\varepsilon_{i, t}
\end{aligned}
$$

Where:

PRII: pressure-resistant institutional investors shareholding ratio, calculated by the percentage of shares held by the total number of securities investment funds, social security funds, and QFII compared to the total shares outstanding,

PSII: pressure-sensitive institutional investors shareholding ratio, calculated by the percentage of shares held by the total number of insurance companies, trust companies, securities companies, financial companies compared to the total shares outstanding, The definitions and calculations for all variables are presented in Appendix A.

\section{Empirical results}

\subsection{Descriptive statistics}

Table 2 Panel A shows the overall descriptive statistics of the variables used in our analysis. The mean value of income smoothing (IS) is 0.9155 , indicating that about $92 \%$ of the firms in our sample period had smooth income.

\begin{tabular}{|c|c|c|c|c|c|c|c|c|c|}
\hline Panel A & & $\mathbf{N}$ & & Min & \multicolumn{2}{|c|}{ Max } & \multicolumn{2}{|l|}{ Mean } & St.Devi \\
\hline IS & & 5049 & & -0.9884 & \multicolumn{2}{|c|}{0.9999} & \multicolumn{2}{|l|}{0.9155} & 0.1959 \\
\hline CONT & & 5049 & & 0.0000 & \multicolumn{2}{|c|}{1.0000} & \multicolumn{2}{|l|}{0.6879} & 0.4634 \\
\hline INST & & 5049 & & 0.0000 & \multicolumn{2}{|c|}{0.6304} & \multicolumn{2}{|l|}{0.0660} & 0.0787 \\
\hline PRII & & 5049 & & 0.0000 & \multicolumn{2}{|c|}{0.6100} & \multicolumn{2}{|l|}{0.0485} & 0.0703 \\
\hline PSII & & 5049 & & 0.0000 & \multicolumn{2}{|c|}{0.5882} & \multicolumn{2}{|l|}{0.0175} & 0.0338 \\
\hline SIZE & & 5049 & & 19.4857 & \multicolumn{2}{|c|}{27.4677} & \multicolumn{2}{|l|}{22.7548} & 1.2429 \\
\hline LEV & & 5049 & & 0.0071 & \multicolumn{2}{|c|}{1.0564} & \multicolumn{2}{|l|}{0.4919} & 0.1905 \\
\hline ROA & & 5049 & & -0.5541 & \multicolumn{2}{|c|}{0.3840} & \multicolumn{2}{|l|}{0.0384} & 0.0505 \\
\hline $\mathrm{BM}$ & & 5049 & & 0.0373 & \multicolumn{2}{|c|}{6.5459} & \multicolumn{2}{|l|}{0.6862} & 0.2744 \\
\hline \multirow[t]{2}{*}{ PanelB } & & $\mathrm{CONT}=1$ & $\mathrm{~N}=3473$ & & \multicolumn{2}{|c|}{$\mathrm{CONT}=\mathbf{0}$} & \multicolumn{2}{|l|}{$\mathrm{N}=1576$} & \multirow[t]{2}{*}{ t-test } \\
\hline & Min & Max & Mean & $\overline{\text { St.Devi }}$ & Min & Max & Mean & $\overline{\text { St.Devi }}$ & \\
\hline IS & -0.6974 & 0.9998 & 0.9224 & 0.1804 & -0.9884 & 0.9999 & 0.9002 & 0.2258 & $3.444^{* * *}$ \\
\hline INST & 0.0000 & 0.6100 & 0.0607 & 0.0720 & 0.0000 & 0.6304 & 0.0774 & 0.0908 & $-6.413^{* * *}$ \\
\hline PRII & 0.0000 & 0.6100 & 0.0446 & 0.0640 & 0.0000 & 0.5393 & 0.0570 & 0.0822 & $-5.314^{* * *}$ \\
\hline PSII & 0.0000 & 0.3841 & 0.0161 & 0.0293 & 0.0000 & 0.5882 & 0.0203 & 0.0419 & $-3.606^{* * *}$ \\
\hline SIZE & 19.6398 & 27.4677 & 22.8365 & 1.2781 & 19.4857 & 26.5368 & 22.5750 & 1.1415 & $7.261^{* * *}$ \\
\hline LEV & 0.0188 & 1.0564 & 0.5050 & 0.1893 & 0.0071 & 0.9484 & 0.4631 & 0.1894 & $7.283^{* * *}$ \\
\hline ROA & -0.4505 & 0.3809 & 0.0342 & 0.0440 & -0.5541 & 0.3840 & 0.0478 & 0.0614 & $-7.903^{* * *}$ \\
\hline $\mathrm{BM}$ & 0.0373 & 6.5459 & 0.7154 & 0.2779 & 0.0394 & 1.3953 & 0.6217 & 0.2551 & $11.384^{* * *}$ \\
\hline
\end{tabular}

Table 2. Descriptive Statistics

Note: $1 .{ }^{*} \mathrm{p}<0.1^{* *} \mathrm{p}<0.05^{* * *} \mathrm{p}<0.01$

2. The variables are defined in Appendix A. 
In the sample listed companies, the proportion of state-controlled firms (CONTs) is $68.79 \%$, indicating that CONTs, as enterprises of special nature, need to focus on analysis and research. The average shareholding of institutional investors (INST) is 0.066, indicating that the ownership of institutional investors accounted for $6.6 \%$ of the firm's shares during the sample period, among which the mean value of pressure-resistant institutional investors (PRII) is 0.0485, and the mean value of pressure-sensitive institutional investors (PSII) is 0.0175 . This shows that the main component of institutional investors in firms is PRII. The average return on assets (ROA) is 0.0384 , indicating that sample firms are profitable overall.

Panel B shows the descriptive statistics after distinguishing the nature of stock rights. In terms of whether firms engage in income smoothing behavior, the proportion of CONTs is $92.24 \%$, and that of non-CONTs is $90.02 \%$. Although the difference between the two is not very large, it still shows that most listed firms in China participate in income smoothing behavior, among which CONTs are more prominent. Secondly, the shareholding ratio of total institutional investors, the mean proportion of PRII, and PSII in non-CONTs are higher than that in CONTs, which may be because CONTs have slightly higher requirements for institutional investors.

Figure 1 reflects the proportion of heterogeneous institutional investors' shareholding to the total holdings of institutional investors from 2011 to 2019. It can be seen from the figure that the proportion of the PRII in the total holdings of institutional investors is decreasing year by year, while the proportion of the PSII is increasing. There are two reasons for this result. First, the reduction in the holdings of PRII leads to a reduction in the holdings of total INST, resulting in a decline in the proportion; Second, the PSII has achieved rapid development, increasing the ratio.

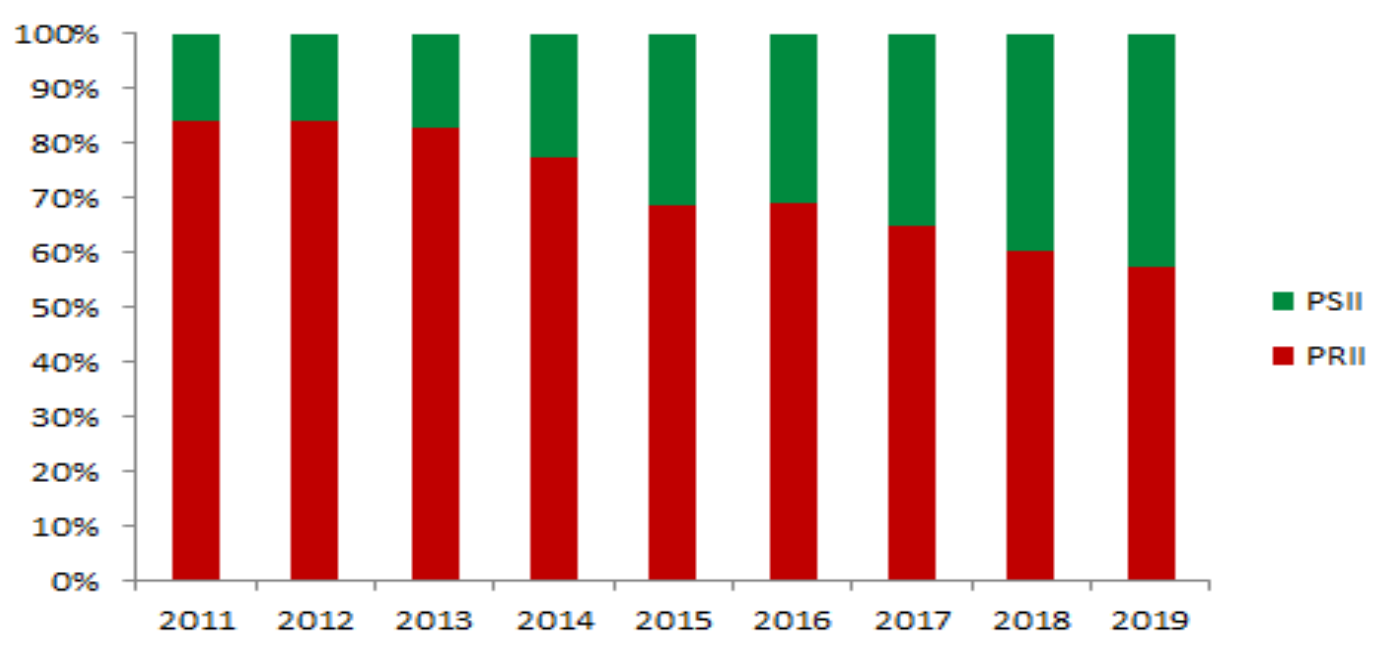

Figure 1. Shareholding distribution of heterogeneous institutional investors from 2011 to 2019

According to the classification method of heterogeneous institutional investors, this study divides INST into PRII and PSII. The descriptive statistics of the proportion of heterogeneous institutional investors are shown in Table 3. The observed value of PRII is 4905, and the mean shareholding ratio is $4.85 \%$, which is significantly higher than the mean shareholding ratio of PSII (1.75\%). This indicates that PRII occupies the main force in the shareholding of institutional 
investors in most firms. Securities investment fund (Fund) is the earliest institutional investor in China and plays a dominant role in the capital markets. In the composition of PRII, we can see that the highest shareholding of Fund is $4.36 \%$. The number of QFII samples is only 530 because China's listed companies have more restrictions on the entry of QFII and the shareholding ratio of QFII is $1.7 \%$. In PSII, the sample number of insurance companies (ICII) was 5,049, indicating that ICII held shares in all firms. In addition, the difference in shareholding proportions is large, and the average shareholding proportion was only $0.75 \%$. Therefore, ICII's shareholding goal might only be short-term profits. Finance companies (FCIIs) have the smallest sample size, and the maximum shareholding is only $0.68 \%$, which indicates that the development of FCIIs is limited.

Table 3. Descriptive Statistics of Heterogeneous Institutional Investors' Shareholding Ratio

\begin{tabular}{cccccc}
\hline & $\mathbf{N}$ & Min & Max & Mean & St.Devi \\
\hline PRII & 5049 & 0.0000 & 0.6100 & 0.0485 & 0.0703 \\
FUND & 4905 & 0.0000 & 0.5629 & 0.0436 & 0.0652 \\
QFII & 530 & 0.0005 & 0.1932 & 0.0170 & 0.0252 \\
SFII & 1187 & 0.0011 & 0.0972 & 0.0185 & 0.0145 \\
PSII & 5049 & 0.0000 & 0.5882 & 0.0175 & 0.0338 \\
ICII & 5049 & 0.0000 & 0.5882 & 0.0075 & 0.0272 \\
SCII & 1297 & 0.0002 & 0.1101 & 0.0180 & 0.0135 \\
TCII & 1314 & 0.0001 & 0.2500 & 0.0189 & 0.0235 \\
FCII & 132 & 0.0007 & 0.0682 & 0.0164 & 0.0135 \\
\hline
\end{tabular}

Note: The variables are defined in Appendix A.

\subsection{Correlation analysis}

Table 4 shows the correlation between the research variables. Through the correlation analysis results, it can be seen that IS has a significant positive correlation with CONT, INST, PRII, PSII, which is consistent with the predicted symbolic direction of the previous hypothesis.

Table 4. Pearson Correlation Coefficient $(\mathrm{N}=5049)$

\begin{tabular}{|c|c|c|c|c|c|c|c|c|c|}
\hline & IS & CONT & INST & PRII & PSII & SIZE & LEV & ROA & $\mathrm{BM}$ \\
\hline IS & 1 & & & & & & & & \\
\hline CONT & $0.053^{* * * *}$ & 1 & & & & & & & \\
\hline INST & $0.044^{* * * *}$ & $-0.098^{* * * * *}$ & 1 & & & & & & \\
\hline PRII & $0.042^{* * * *}$ & $-0.082^{* * * *}$ & $0.903^{* * * *}$ & 1 & & & & & \\
\hline PSII & $0.030^{* * * *}$ & $-0.058^{* * * *}$ & $0.448^{*+1+x}$ & 0.021 & 1 & & & & \\
\hline SIZE & $0.138^{* * *+*}$ & $0.098^{* * *}$ & $0.135^{* * * *}$ & $0.042^{* * * *}$ & $0.227^{* * * *}$ & 1 & & & \\
\hline LEV & $0.137^{* * * *}$ & $0.102^{* * *}$ & $-0.047^{* * * *}$ & $-0.076^{* * * *}$ & $0.044^{* * * *}$ & $0.489^{* * * *}$ & 1 & & \\
\hline ROA & -0.001 & $-0.125^{\text {***** }}$ & $0.320^{* \text { s* }}$ & $0.351^{* * * *}$ & 0.014 & -0.018 & $-0.379^{* * * *}$ & 1 & \\
\hline $\mathrm{BM}$ & $0.118^{* * * *}$ & $0.158^{* * *}$ & $-0.200^{* * * *}$ & $-0.255^{* * *}$ & $0.067^{* * *}$ & $0.584^{* * *}$ & $0.439^{\text {**** }}$ & $-0.283^{* * * *}$ & 1 \\
\hline
\end{tabular}

Note: $1 .{ }^{*} \mathrm{p}<0.1{ }^{* *} \mathrm{p}<0.05^{* * *} \mathrm{p}<0.01$

2. The variables are defined in Appendix A.

We find that CONT is significantly negatively correlated with INST, PRII, and PSII, 
indicating that compared with non-CONTs, the proportion of shares held by institutional investors in CONTs is lower. Therefore, it is valuable to study the role of institutional investors in CONTs. We find that income smoothing is positively correlated with SIZE, LEV, and BM and negatively correlated with ROA. These correlations indicate that when examining the relationship between income smoothing activities, the nature of stock rights, and institutional investors' shareholding, these control factors may affect the importance of managers making income smoothing decisions.

\subsection{Regression Result}

\subsubsection{Nature of stock rights and income smoothing}

From the regression results in Table 5, the coefficient of CONT is positive and significant, indicating that CONTs are more likely to smooth income than non-CONTs. This finding is consistent with the prediction of Hypothesis 1. We can understand this result from two aspects. First, due to the unique political and social relations of CONTs, they will reduce the attention of the public and reduce the cost of political attention by utilizing income smoothing. Secondly, CONTs are usually able to obtain a lot of information and financing advantages, but when the relevant government departments are unable to support the enterprises due to special reasons, managers can use stable income as a preventative measure. CONTs then smooth earnings to communicate private information to investors about business sustainability. The coefficient of SIZE is significantly positively correlated, which is consistent with the analysis results of Watts and Zimmerman [18] that found large companies are more likely to attract the attention of the public and relevant departments, and usually, reduce the "cost of political attention" by smoothing income. The coefficient of LEV is significantly positively correlated, indicating that higher debt levels result in greater motivation for managers to engage in income smoothing. This is consistent with the assumption of a debt contract. The relationship between ROA and IS is significantly positive, indicating that enterprises with high business performance are usually more likely to receive attention, to reduce political cost or tax burden through income smoothing.

Table 5. Nature of stock rights and income smoothing

\begin{tabular}{|c|c|c|c|}
\hline \multicolumn{4}{|c|}{$\mathrm{IS}_{\mathrm{i}, \mathrm{t}}=\alpha_{0}+\alpha_{1} \mathrm{CONT}_{\mathrm{i}, \mathrm{t}}+\alpha_{2} \mathrm{SIZE}_{\mathrm{i}, \mathrm{t}}+\alpha_{3} \mathrm{LEV}_{\mathrm{i}, \mathrm{t}}+\alpha_{4} \mathrm{ROA}_{\mathrm{i}, \mathrm{t}}+\alpha_{5} \mathrm{BM}_{\mathrm{i}, \mathrm{t}}+$ Year and Industry Fixed Effects $+\varepsilon_{\mathrm{i}, \mathrm{t}}$} \\
\hline Variable & Predicted Sign & Coefficient & $\mathrm{t}$-statistic \\
\hline Constant & & 0.589 & $9.381^{* * * *}$ \\
\hline CONT & + & 0.018 & $3.001^{* * * *}$ \\
\hline SIZE & & 0.010 & $3.346^{* * * *}$ \\
\hline LEV & & 0.084 & $4.418^{* * * *}$ \\
\hline ROA & & 0.189 & $3.031^{* * *}$ \\
\hline BM & & 0.026 & $1.942^{*}$ \\
\hline Year & & \multicolumn{2}{|c|}{ Yes } \\
\hline Industry & & \multicolumn{2}{|c|}{ Yes } \\
\hline $\mathrm{n}$ & & \multicolumn{2}{|c|}{5049} \\
\hline Adj. $R^{2}$ & & \multicolumn{2}{|c|}{0,043} \\
\hline F-statistic & & \multicolumn{2}{|c|}{$31.048^{* * * *}$} \\
\hline
\end{tabular}

Note: $1 .{ }^{*} \mathrm{p}<0.1^{* *} \mathrm{p}<0.05^{* * *} \mathrm{p}<0.01$

2. The variables are defined in Appendix A. 
4.3.2 The nature of stock rights, income smoothing, and institutional investors' monitoring

This section reveals whether the regulatory role of institutional investors is positive or negative. If CONTs can reduce income volatility through income smoothing, and the main motivation for smoothing income is to convey useful private information to investors, then we believe that institutional investor regulation plays a positive regulating role in the relationship between CONT and IS, and the interaction coefficient of INST*IS should be positive. If the motive of CONTs to smooth income is for their interests, institutional investors will resist this method, then we believe that institutional investor supervision plays a negative role in regulating the relationship between CONT and IS, and the interaction coefficient of INST*IS should be negative. Through the regression analysis in Table 6, we can see that the interaction coefficients of CONT and INST are significantly positively correlated, indicating that the income smoothing behavior of CONTs is considered to be effective information to communicate with investors, and institutional investors encourage this behavior at this time.

Table 6. Nature of stock rights, income smoothing, and institutional investors' monitoring

\begin{tabular}{|c|c|c|c|c|c|}
\hline \multicolumn{6}{|c|}{$\begin{aligned} I_{i, t}=\beta_{0}+\beta_{1} \operatorname{CONT}_{i, t} & +\beta_{2} I N S T_{i, t}+\beta_{3} \operatorname{CONT}_{i, t} * \operatorname{INST}_{i, t}+\beta_{4} \operatorname{SIZE}_{i, t}+\beta_{5} \mathrm{LEV}_{\mathrm{i}, \mathrm{t}}+\beta_{6} \mathrm{ROA}_{\mathrm{i}, \mathrm{t}}+\beta_{7} \mathrm{BM}_{\mathrm{i}, \mathrm{t}}+\text { Year and Industry Fixed Effects } \\
& +\varepsilon_{\mathrm{i}, \mathrm{t}}\end{aligned}$} \\
\hline Variable & Predicted Sign & Coefficient(1) & $\mathrm{t}$-statistic & Coefficient(2) & $\mathrm{t}$-statistic \\
\hline Constant & & 0.664 & $10.809^{* * * x}$ & 0.678 & $10.972^{* * * *}$ \\
\hline CONT & & 0.016 & $2.704^{* * *}$ & 0.006 & 0.752 \\
\hline INST & & 0.113 & $2.941^{* * *}$ & 0.029 & 0.513 \\
\hline CONT*INST & + & & & 0.147 & $2.567^{*}$ \\
\hline SIZE & & 0.006 & $1.998^{* *}$ & 0.006 & $1.883^{*}$ \\
\hline LEV & & 0.109 & $6.011^{* * * *}$ & 0.109 & $6.005^{* * *}$ \\
\hline ROA & & 0.188 & $2.950^{* * * *}$ & 0.190 & $2.981^{* * *}$ \\
\hline $\mathrm{BM}$ & & 0.046 & $3.437^{* * *}$ & 0.048 & $3.524^{* * * *}$ \\
\hline Year & & \multicolumn{2}{|c|}{ Yes } & \multicolumn{2}{|c|}{ Yes } \\
\hline Industry & & \multicolumn{2}{|c|}{ Yes } & \multicolumn{2}{|c|}{ Yes } \\
\hline$n$ & & \multicolumn{2}{|c|}{5049} & \multicolumn{2}{|c|}{5049} \\
\hline Adj. $R^{2}$ & & \multicolumn{2}{|c|}{0.035} & \multicolumn{2}{|c|}{0.032} \\
\hline F-statistic & & \multicolumn{2}{|c|}{$27.354^{* * *}$} & \multicolumn{2}{|c|}{$24.084^{* * * *}$} \\
\hline
\end{tabular}

Note: $1 .{ }^{*} \mathrm{p}<0.1^{* *} \mathrm{p}<0.05^{* * *} \mathrm{p}<0.01$

2. The variables are defined in Appendix A.

4.3.3 Nature of stock rights, income smoothing, and institutional investor's heterogeneity

In the regression analysis in Table 7, we have judged that the motivation of the income smoothing of CONTs is mainly due to the efficient communication of private information to the public, and this behavior is supported by institutional investors. However, institutional investors' investment motives differ, so it cannot be concluded that all institutional investors are playing a positive supervisory role. According to the independence of institutional investors, this paper is divided into PRII and PSII. This part mainly tests the heterogeneous effect of PRII and PSII and studies the attitudes of PRII and PSII in dealing with the relationship between CONT and IS. As can be seen from the results in Table 6, the coefficient of PRII*INST is significantly positively correlated, while the coefficient of PSII*INST is positive but not 
significant, indicating that the effective supervision role of institutional investors is largely driven by PRII, and the independence of institutional investors cannot be ignored.

Table 7. Nature of stock rights, income smoothing, and institutional investors' monitoring

\begin{tabular}{|c|c|c|c|c|c|}
\hline \multicolumn{6}{|c|}{$\begin{array}{c}\text { IS }_{i, t}=\gamma_{0}+\gamma_{1} \operatorname{CONT}_{i, t}+\gamma_{2} \text { PRII }_{i, t}+ \\
\gamma_{3} \operatorname{CONT}_{i, t} * \text { PRII }_{i, t}+\gamma_{4} \text { PSII }_{i, t}+\gamma_{5} \operatorname{CONT}_{i, t} * \text { PSII }_{i, t}+\gamma_{6} \text { SIZE }_{i, t}+\gamma_{7} \mathrm{LEV}_{i, t}+\gamma_{8} \text { ROA }_{i, t}+ \\
\gamma_{9} \text { BM }_{i, t}+\text { Year and Industry Fixed Effects }+\varepsilon_{i, t}\end{array}$} \\
\hline Variable & \multirow[t]{2}{*}{ Predicted Sign } & \multirow[t]{2}{*}{ Coefficient(1) } & \multirow{2}{*}{$\frac{\text { t-statistic }}{10.753^{* * * *}}$} & \multirow{2}{*}{$\begin{array}{c}\text { Coefficient(2) } \\
0.683\end{array}$} & \multirow{2}{*}{$\begin{aligned} \text { t-statistic } \\
10.937^{* * *}\end{aligned}$} \\
\hline Constant & & & & & \\
\hline CONT & & 0.038 & $2.720^{* * * * *}$ & 0.005 & 0.659 \\
\hline PRII & & 0.038 & $2.46^{* *}$ & 0.036 & 0.582 \\
\hline CONT*PRII & + & & & 0.270 & $2.170^{* * *}$ \\
\hline PSII & & 0.024 & $1.686^{*}$ & -0.003 & -0.025 \\
\hline $\mathrm{CONT}^{*} \mathrm{PSII}$ & $?$ & & & 0.118 & 1.507 \\
\hline SIZE & & 0.038 & $1.925^{*}$ & 0.006 & $1.788^{*}$ \\
\hline LEV & & 0.107 & $6.020^{* * * *}$ & 0.110 & $6.030^{* * * *}$ \\
\hline $\mathrm{ROA}$ & & 0.049 & $2.972^{* * *}$ & 0.193 & $2.991^{* * *+}$ \\
\hline $\mathrm{BM}$ & & 0.065 & $3.410^{* * *}$ & 0.048 & $3.514^{* * * *}$ \\
\hline Year & & \multicolumn{2}{|c|}{ Yes } & \multicolumn{2}{|c|}{ Yes } \\
\hline Industry & & \multicolumn{2}{|c|}{ Yes } & \multicolumn{2}{|c|}{ Yes } \\
\hline $\mathrm{n}$ & & \multicolumn{2}{|c|}{5049} & \multicolumn{2}{|c|}{5049} \\
\hline Adj. $R^{2}$ & & \multicolumn{2}{|c|}{0.048} & \multicolumn{2}{|c|}{0.033} \\
\hline F-statistic & & \multicolumn{2}{|c|}{$23.462^{2 * *+*}$} & \multicolumn{2}{|c|}{$18.826^{* * * *+}$} \\
\hline
\end{tabular}

Note: $1 .{ }^{*} \mathrm{p}<0.1^{* *} \mathrm{p}<0.05^{* * *} \mathrm{p}<0.01$

2. The variables are defined in Appendix A.

\subsection{Robustness test}

To ensure the reliability of the research conclusions and increase the explanatory power of institutional investors' supervisory function, we use the institutional investors' shareholding checks and balances (INST-CB) to replace the shareholding proportion of institutional investors in the regression analysis and verify the moderating effect of institutional investors on CONTs and income smoothing. The INST-CB is a measure of institutional investors' ability to participate in corporate governance. The INST-CB in this paper refers to the ratio of institutional investors' shareholding to the largest shareholder of a company. Boyd and Smith [61] believe that institutional investors' holding could restrain the plunder of minority shareholders by major shareholders. Xia Bo [62] found that the greater the degree of checks and balances of foreign institutional investors, the more able they are to participate in corporate governance and improve corporate performance. When CONTs convey useful private information through income smoothing, institutional investors play a positive regulating role, and this positive regulating role is largely driven by PRII. 
Table 8. Robustness test

\begin{tabular}{|c|c|c|c|c|c|}
\hline \multicolumn{6}{|c|}{ 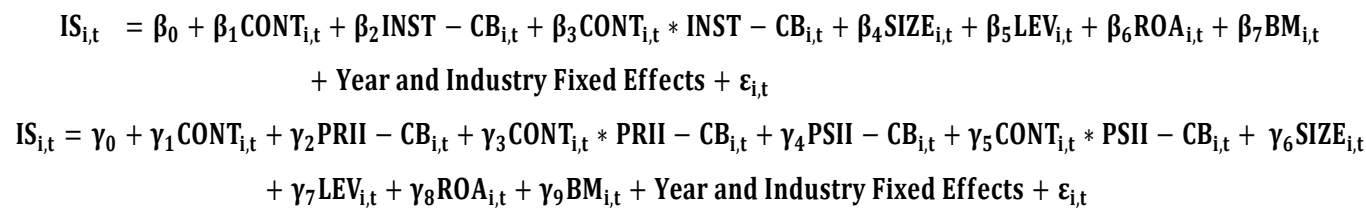 } \\
\hline Variable & Predicted Sign & Coefficient(1) & t-statistic & Coefficient(2) & t-statistic \\
\hline Constant & & 0.646 & $10.675^{* * *}$ & 0.643 & $10.566^{* * *}$ \\
\hline CONT & & 0.004 & 0.569 & 0.003 & 0.388 \\
\hline INST-CB & & -0.011 & -1.211 & & \\
\hline CONT*INST-CB & + & 0.045 & $3.261^{* * *}$ & & \\
\hline PRII-CB & & & & -0.039 & $-1.731^{*}$ \\
\hline CONT*PRII-CB & + & & & 0.090 & $2.438^{* *}$ \\
\hline PSII-CB & & & & -0.003 & -0.283 \\
\hline CONT*PSII-CB & $?$ & & & 0.034 & $1.893^{*}$ \\
\hline SIZE & & 0.008 & $2.517^{* *}$ & 0.008 & $2.555^{* *}$ \\
\hline LEV & & 0.109 & $6.028^{* * *}$ & 0.109 & $5.984^{* * *}$ \\
\hline $\mathrm{ROA}$ & & 0.212 & $3.382^{* * *}$ & 0.205 & $3.226^{* * *}$ \\
\hline $\mathrm{BM}$ & & 0.041 & $3.101^{* * * *}$ & 0.0482 & $3.152^{* * * *}$ \\
\hline Year & & & & & \\
\hline Industry & & & & & \\
\hline $\mathrm{n}$ & & & & & \\
\hline Adj. $R^{2}$ & & & & & \\
\hline F-statistic & & & & & \\
\hline
\end{tabular}

Note: $1 .{ }^{*} \mathrm{p}<0.1^{* *} \mathrm{p}<0.05^{* * *} \mathrm{p}<0.01$

2. The variables are defined in Appendix A.

\section{Conclusion}

To the best of our knowledge, this study is the first to examine the link between the nature of stock rights and income smoothing in China. Under the special institutional background in China, CONTs have a close relationship with government agencies and have a strong political connection. Although they have many advantages in obtaining resources, they also need to undertake corresponding economic and social responsibilities for the sustainable economic development and social stability of the country. Although market-oriented reform has improved the governance structure of CONTs and non-CONTs, there are still differences. And many of China's listed companies are controlled by the state, which is not negligible. In addition, although there are studies on the nature of stock rights and earnings management, there is a lack of empirical research on income smoothing. Therefore, this paper believes that it is necessary to consider the nature of stock rights and distinguish the relationship between research on CONTs and non-CONTs and earnings smoothing. Considering whether institutional investors, as an important part of capital markets, play an active supervisory role, it is of certain practical significance to explore the regulatory role of institutional investors in the relationship between the nature of stock rights and income smoothing.

The empirical results of this paper provide evidence both in a practical sense and for academic research and fill in several gaps in the literature, which can be explained mainly from 
the following aspects: First, the empirical research results show that compared with nonCONTs, CONTs are more likely to conduct income smoothing. This result is consistent with the political cost hypothesis [18], reputation theory, and signal theory. It is believed that the public pays relatively greater attention to CONTs, so managers may use income smoothing strategies to reduce public attention. Secondly, usually, stable income represents the effective operation of the company. Institutional investors prefer the stable income flow of CONTs. On the one hand, it can reflect the correct choice of institutional investors and maintain their reputation. On the other hand, it can reflect the active monitoring role of institutional investors and shareholders. The most important thing is that only when the income smoothing behavior is considered to convey useful information to investors and other stakeholders, this approach will be supported by institutional investors. Finally, this paper suggests that the heterogeneity of institutional investors takes the independence of institutional investors as the classification standard and concludes that the positive moderating effect of institutional investors on CONTs and income smoothing mainly comes from the PRII. Therefore, this paper not only expands on the dimensions of China's nature of stock rights and institutional investors but also fills in the shortcomings of empirical research on income smoothing.

Overall, these findings have added to our knowledge of the income smoothing strategy, why different researchers hold different attitudes toward income smoothing because it is impossible to consider all factors, the institutional structure and investors to participate in the attitude of different countries, and management characteristics will affect the income smoothing approach. In addition, according to different characteristics, the main body of institutional investors can be divided into different types, so this paper only considers the independence of institutional investors' business links, and there is still room for further research. 


\section{Appendix A Definition of Variables}

\begin{tabular}{|c|c|}
\hline Variables & Definition \\
\hline IS & $\begin{array}{l}\text { Income smoothing, the negative correlation between the change in discretionary- } \\
\text { accruals }(\triangle \mathrm{DA}) \text { and pre-discretionary income }(\triangle \mathrm{PDI})\end{array}$ \\
\hline CONT & $\begin{array}{l}\text { A dummy variable indicates } 1 \text {, If the listed company equity nature is state- } \\
\text { controlled, and zero otherwise }\end{array}$ \\
\hline INST & $\begin{array}{l}\text { The proportion of shares held by institutional investors to total shares } \\
\text { outstanding }\end{array}$ \\
\hline PRII & FUND+QFII+SFII \\
\hline PSII & ICII+SCII+TRII+FCII \\
\hline INST-CB & $\begin{array}{l}\text { The ratio of institutional investors' shareholding to the largest shareholder of a } \\
\text { company }\end{array}$ \\
\hline PRII-CB & $\begin{array}{l}\text { The ratio of pressure-resistant institutional investors' shareholding to the largest } \\
\text { shareholder of a company }\end{array}$ \\
\hline PSII-CB & $\begin{array}{l}\text { The ratio of pressure-sensitive institutional investors' shareholding to the largest } \\
\text { shareholder of a company }\end{array}$ \\
\hline FUND & $\begin{array}{l}\text { The proportion of shares held by securities investment fund institutional } \\
\text { investors to total shares outstanding }\end{array}$ \\
\hline QFII & $\begin{array}{l}\text { The proportion of shares held by qualified foreign institutional investors to total } \\
\text { shares outstanding }\end{array}$ \\
\hline SFII & $\begin{array}{l}\text { The proportion of shares held by social security fund institutional investors to } \\
\text { total shares outstanding }\end{array}$ \\
\hline ICII & $\begin{array}{l}\text { The proportion of shares held by insurance company institutional investors to } \\
\text { total shares outstanding }\end{array}$ \\
\hline SCII & $\begin{array}{l}\text { The proportion of shares held by securities company institutional investors to } \\
\text { total shares outstanding }\end{array}$ \\
\hline TCII & $\begin{array}{l}\text { The proportion of shares held by trust company institutional investors to total } \\
\text { shares outstanding }\end{array}$ \\
\hline FCII & $\begin{array}{l}\text { The proportion of shares held by financial company institutional investors to } \\
\text { total shares outstanding }\end{array}$ \\
\hline SIZE & Natural log of total assets \\
\hline LEV & Total debts scaled total assets \\
\hline $\mathrm{ROA}$ & Income before extraordinary items scaled total assets \\
\hline $\mathrm{BM}$ & Book value scaled market value \\
\hline
\end{tabular}




\section{References}

1. Bhattacharya, U., H. Daouk, and M. Welker, The world price of earnings opacity. The accounting review, 2003. 78(3): p. 641-678.

2. Tucker, J.W. and P.A. Zarowin, Does income smoothing improve earnings informativeness? The accounting review, 2006. 81(1): p. 251-270.

3. Healy, P.M., The effect of bonus schemes on accounting decisions. Journal of accounting and economics, 1985. 7(1-3): p. 85-107.

4. Graham, J.R., C.R. Harvey, and S. Rajgopal, The economic implications of corporate financial reporting. Journal of accounting and economics, 2005. 40(1-3): p. 3-73.

5. Leuz, C., D. Nanda, and P.D. Wysocki, Earnings management and investor protection: an international comparison. Journal of financial economics, 2003. 69(3): p. 505-527.

6. Velury, U. and D.S. Jenkins, Institutional ownership and the quality of earnings. Journal of business research, 2006. 59(9): p. 1043-1051.

7. Lu Jiayou and Li Yanmei, Institutional Investor ownership, Internal Control, and corporate Performance: A division based on state-controlled and non-state-controlled firms. Finance and accounting bulletin, 2019. 12.

8. Hu, Y., J. Shan, and P. Zhan, Institutional Investors' Corporate Site Visits and Firms' Sustainable Development. Sustainability, 2020. 12(17).

9. Li Zhengguang, Guo Haoran, Ding Mengyun, and Li Ping, Institutional investor heterogeneity and financial fraud. Chinese Certified Public Accountant, 2020. 256(09): p 49-54.

10. Sahut, J.-M., S. Gharbi, and H.O. Gharbi, Stock volatility, institutional ownership and analyst coverage. Bankers, Markets and Investors, 2011. 110: p. 21-30.

11. Brickley, J.A., R.C. Lease, and C.J. Smith, Ownership structure and voting on antitakeover amendments. Journal of financial economics, 1988. 20.

12. Li, Y., et al., Corporate Public Transparency on Financial Performance: The Moderating Role of Political Embeddedness. Sustainability, 2019. 11(19).

13. Tee, C.M., Political connections and income smoothing: Evidence of institutional investors' monitoring in Malaysia. Journal of multinational financial management, 2020. 55: p. 100626.

14. Koh, P.S., Institutional ownership and income smoothing: Australian evidence. Accounting research journal, 2005.

15. Shi Yongdong and Wang Jingle, Have Chinese institutional investors really stabilized the market? Economic research journal, 2014. 049(012): p. 100-112.

16. Kirschenheiter, M. and N.D. Melumad, Can "big bath" and earnings smoothing co-exist as equilibrium financial reporting strategies? Journal of Accounting Research, 2002. 40(3): p. 761-796.

17. Yang jisheng and Yang Jianhui, Administrative monopoly, Political Patronage and excess costs of State-controlled firms. Economic research journal, 2015(04): p. 52-63+108.

18. Watts, R.L. and J.L. Zimmerman, Positive accounting theory. 1986.

19. Wang Peng, Dou Huan, and Liu Weiyi, Internal control quality, Corporate characteristics and earnings quality. Chinese Certified Public Accountant, 2013. 000(002): p. 45-51.

20. Wu Gaobo and He Fangfang, Media attention and earnings management: The Moderating role of ownership. International Business and Accounting, 2018. 000(006): p. 36-40,48.

21. Zhou Hui, Ma Rui, and Zhu Jiuhua, Executive compensation incentive and earnings management in State-controlled Listed Companies in China. Financial Theory E Practice, 2010(04): p. 48-52. 
22. Sankar, M.R. and K. Subramanyam, Reporting discretion and private information communication through earnings. Journal of accounting research, 2001. 39(2): p. 365-386.

23. Michelson, S.E., J. Jordan-Wagner, and C.W. Wootton, The relationship between the smoothing of reported income and risk-adjusted returns. Journal of economics and finance, 2000. 24(2): p. 141159.

24. Zheng Xincheng, Price reaction of Chinese A-share Stock market to Earnings management -using manipulable accruals as characterization variable. 2005.

25. Song Zengji, Feng Liming, and Tan Xingmin, State-controlled equity, Private Entrepreneurs' participation in politics and enterprise financing convenience: Empirical evidence from China's private holding listed companies. Financial Research, 2014. 000(012): p. 133-147.

26. Yang Beijing and Feng Lu, State-controlled equity, Corporate Social Responsibility and Credit constraints. Financial Forum, 2019. 2.

27. Chakravarty, S., V. Panchapagesan, and R.A. Wood, Institutional trading patterns and price impact around decimalization. Paper-institute for Research in the Behavioral Economic and Management Sciences Purdue University Krannert Graduate School of Management, 2001.

28. Sakawa, H. and N. Watanabel, Institutional Ownership and Firm Performance under Stakeholder-Oriented Corporate Governance. Sustainability, 2020. 12(3).

29. Song $\mathrm{Yu}$ and Fan Minhong, Institutional Investor holdings, Future Earnings and Stock price Information Content- - with the difference between securities investment Funds and QFII. East China Economic Management, 2013(1): p. 102-106.

30. Luo, M., T. Chen, and I.K. Yan, Price informativeness and institutional ownership: evidence from Japan. Review of Quantitative Finance and Accounting, 2014. 42(4): p. 627-651.

31. Bo Xianhui and $\mathrm{Wu}$ Liansheng, Governance effects of state-controlled holding and institutional investors: an earnings management perspective. Economic Research Journal, 2009. 2(8).

32. Li Zengfu, Lin Shengtian, and Lian Yujun, State-controlled holdings, Institutional Investors and earnings management of real Activities. Journal of Management Engineering, 2013(3): p. 35-44.

33. Morck, R., A. Shleifer, and R.W. Vishny, Management ownership and corporate performance: An empirical analysis. National Bureau of Economic Research Cambridge, Mass., USA, 1986.

34. Menkhoff, L., M. Schmeling, and U. Schmidt, Are all professional investors sophisticated? German Economic Review, 2010. 11(4): p. 418-440.

35. Kochhar, R. and P. David, Institutional investors and firm innovation: A test of competing hypotheses. Strategic management journal, 1996. 17(1): p. 73-84.

36. Ding FangFei, et al., Institutional Investor Ownership, Earnings Management and market Reaction. Financial Theory E Practice, 2013. 34(4): p 59-63.

37. Gong Guangming and Peng Juan, Accounting information quality, Investment Efficiency and institutional investor Heterogeneity. Friends of Accounting, 2014. 000(033): p. 93-99.

38. Chen Shen, Chen Yanmiao, and Du Meng, institutional investors and management collusion or mutual restraint?-- Empirical research from the perspective of property rights. Journal of Nanjing University of Finance and Economics, 2015. 000(001): p. 74-86.

39. Mehrani, S., M. Moradi, and H. Eskandar, Institutional ownership type and earnings quality: Evidence from Iran. Emerging Markets Finance and Trade, 2017. 53(1): p. 54-73.

40. Shin, I. and S. Park, Role of Foreign and Domestic Institutional Investors in Corporate Sustainability: Focusing on R\&D Investment. Sustainability, 2020. 12(20).

41. Qin, Z. An empirical study on the Impact of equity ownership of heterogeneous Institutional 
Investors on earnings Sustainability. Capital University of Economics and Business, 2018.

42. Hepworth, S.R., Smoothing periodic income. The accounting review, 1953. 28(1): p. 32-39.

43. Huang, S., C. Lyu, and X. Lin, Is Labor Related to the Duality of Earnings Smoothing? Sustainability, 2018. 10(12).

44. Yi Zhihong, Li Yanli, and Gao Wei, Marketization process, Institutional Investors and compensation Incentive. Economic Theory and Management, 2011. 000(010): p. 75-84.

45. Yang Haiyan, Wei Dehong, and Sun Jian. Can Institutional Investor Ownership Improve the Quality of Accounting Information of Listed Companies?-- Also on the differences of different types of institutional investors. Accounting Research, 2012. 000(009): p. 16-23.

46. Bushee, B.J., Do institutional investors prefer near - term earnings over long - run value? Contemporary Accounting Research, 2001. 18(2): p. 207-246.

47. Koh, P.-S., Institutional investor type, earnings management and benchmark beaters. Journal of Accounting and Public Policy, 2007. 26(3): p. 267-299.

48. Dong, M. and A. Ozkan, Institutional investors and director pay: An empirical study of UK companies. Journal of Multinational Financial Management, 2008. 18(1): p. 16-29.

49. Cornett, M.M., et al., The impact of institutional ownership on corporate operating performance. Journal of Banking E Finance, 2007. 31(6): p. 1771-1794.

50. Ferreira, M.A. and P. Matos, The colors of investors' money: The role of institutional investors around the world. Journal of financial economics, 2008. 88(3): p. 499-533.

51. Aggarwal, R., et al., Does governance travel around the world? Evidence from institutional investors. Journal of financial economics, 2011. 100(1): p. 154-181.

52. Incheol, et al., Drivers behind the monitoring effectiveness of global institutional investors: Evidence from earnings management. Journal of corporate finance, 2016.

53. Almazan, A., J.C. Hartzell, and L.T. Starks, Active institutional shareholders and costs of monitoring: Evidence from executive compensation. Financial Management, 2005. 34(4): p. 5-34.

54. Chen, X., J. Harford, and K. Li, Monitoring: Which institutions matter? Journal of financial economics, 2007. 86(2): p. 279-305.

55. Wang, M., Which Type of Institutional Investors Constrains Abnormal Accruals? 2014.

56. Li Zengfu and Zhou Ting, Size, Nature of Controller and Earnings Management. Nankai Management Review, 2013. 16(006): p 81-94.

57. Lei Guangyong and Liu Huilong, major shareholder control, financing scale and earnings manipulation degree. Management World, 2006(1): p. 129-136.

58. Chen Donghua, On the empirical Research of earnings management should be moralized. 2009.

59. Lakonishok, J., A. Shleifer, and R.W. Vishny, Contrarian investment, extrapolation, and risk. The journal of finance, 1994. 49(5): p. 1541-1578.

60. Abdalla, A.M., The Power of Aggregate Book-to-Market Innovations: Forecasting, Nowcasting, and Dating the Real Economy. Social Science Electronic Publishing, 2016.

61. Boyd, J. and B. Smith, The coevolution of the real and financial sectors in the growth process. The World Bank Economic Review, 1996. 10(2): p. 371-396.

62. Xia Bo, An Empirical Study on the Impact of QFII Shareholding on the Performance of Listed Companies. Dongbei University of Finance and Economics, 2013. 